\title{
Copper(2+) complexes of hydroxyoxidopolyborates: Synthesis and characterization of [Cu(MeNHCH2CH2NMeH)2(H2O)2][B5O6(OH)4]2.2B(OH)3.
}

\author{
Altahan, Mohammed A.; Beckett, Michael A.; Coles, Simon J.; Horton, Peter N.
}

\section{Phosphorus, Sulfur and Silicon and the Related Elements}

DOI:

10.1080/10426507.2019.1631307

Published: 03/10/2019

Peer reviewed version

Cyswllt i'r cyhoeddiad / Link to publication

Dyfyniad o'r fersiwn a gyhoeddwyd / Citation for published version (APA):

Altahan, M. A., Beckett, M. A., Coles, S. J., \& Horton, P. N. (2019). Copper(2+) complexes of hydroxyoxidopolyborates: Synthesis and characterization of

[Cu(MeNHCH2CH2NMeH)2(H2O)2][B5O6 $(\mathrm{OH}) 4] 2.2 \mathrm{~B}(\mathrm{OH}) 3$. Phosphorus, Sulfur and Silicon and the Related Elements, 194(10), 948-951. https://doi.org/10.1080/10426507.2019.1631307

\footnotetext{
Hawliau Cyffredinol / General rights

Copyright and moral rights for the publications made accessible in the public portal are retained by the authors and/or other copyright owners and it is a condition of accessing publications that users recognise and abide by the legal requirements associated with these rights.

- Users may download and print one copy of any publication from the public portal for the purpose of private study or research.

- You may not further distribute the material or use it for any profit-making activity or commercial gain

- You may freely distribute the URL identifying the publication in the public portal ?
}

If you believe that this document breaches copyright please contact us providing details, and we will remove access to the work immediately and investigate your claim. 


\title{
Copper $(2+]$ complexes of hydroxyoxidopolyborates: Synthesis and characterization of $\left[\mathrm{Cu}\left(\mathrm{MeNHCH}{ }_{2} \mathrm{CH}_{2} \mathrm{NMeH}_{2}\left(\mathrm{H}_{2} \mathrm{O}_{2}\right]\left[\mathrm{B}_{5} \mathrm{O}_{6}(\mathrm{OH}]_{4}\right]_{2} 2 \mathrm{~B}(\mathrm{OH})_{3}\right.\right.$.
}

\author{
Mohammed A. Altahan ${ }^{\S a}$, Michael A. Beckett*a, Simon J. Coles ${ }^{b}$, Peter N. Horton ${ }^{b}$ \\ ${ }^{a}$ School Natural Sciences, Bangor University, Bangor, LL57 2SX, UK \\ ${ }^{\mathrm{b}}$ Chemistry, University of Southampton, Southampton, SO17 1BG, UK \\ * Author for correspondence: m.a.beckett@bangor.ac.uk; \\ $\S$ Current address: Chemistry Department, College of Science, University of Thi-Qar, Nasiriyah, Iraq
}

\begin{abstract}
A$ The pentaborate(1-) salt, $\left[\mathrm{Cu}(\text { dmen })_{2}\left(\mathrm{H}_{2} \mathrm{O}\right)_{2}\right]\left[\mathrm{B}_{5} \mathrm{O}_{6}(\mathrm{OH})_{4}\right]_{2} \cdot 2 \mathrm{~B}(\mathrm{OH})_{3}\left(\right.$ dmen $=N, N^{\prime}$-dimethylethylenediamine, $\mathrm{MeHNCH}_{2} \mathrm{CH}_{2} \mathrm{NHMe}$ ), has been synthesized in $48 \%$ yield as a crystalline product by reaction of $\mathrm{B}(\mathrm{OH})_{3}$ with $\left.\left[\mathrm{Cu}(\text { dmen })_{2}\right](\mathrm{OH})_{2}\right]_{2}(10: 1$ ratio) in aqueous solution. Single-crystal XRD analysis confirms its ionic structure with one interstitial $\mathrm{B}(\mathrm{OH})_{3}$ per pentaborate(1-) unit. The pentaborate(1-) anions and $\mathrm{B}(\mathrm{OH})_{3}$ molecules are involved in a supramolecular giant $\mathrm{H}$-bonded lattice with $\mathrm{B}(\mathrm{OH})_{3}$ units serving as 'spacers' to help accommodate the relatively large $\left[\mathrm{Cu}(\mathrm{dmen})_{2}\left(\mathrm{H}_{2} \mathrm{O}\right)_{2}\right]^{2+}$ cations.
\end{abstract}

GRAPHICAL ABSTRACT
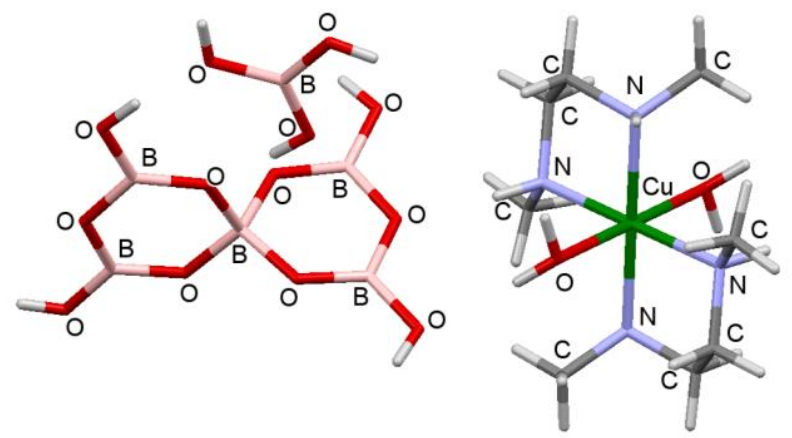

KEYWORDS Copper(2+) complexes; Boric acid; Oxidoborates; Pentaborate(1-); Polyborates; X-ray structure

\section{INTRODUCTION}

Hydroxyoxidopolyborate salts may be synthesized from the addition of $\mathrm{B}(\mathrm{OH})_{3}$ to a basic aqueous solution containing templating cations or by solvothermal methods. ${ }^{[1]}$ Hydroxyoxidopolyborate salts obtained from aqueous solution are usually comprised of discrete, insular anions, partnered by the templating cations. These salts are often pentaborate(1-) salts since the 
pentaborate(1-) anion is well adapted to forming a wide variety of crystalline lattices, held together by strong H-bond interactions. ${ }^{[2-5]}$ In our search for novel hydroxyoxidopolyborate anions we have adopted a strategy of using transition-metal complexes as templating agents. We have recently reported the synthesis of several salts containing isolated polyborate anions partnered with transition-metal complexes and have described the synthesis and structures of two novel isolated polyborate salts containing the heptaborate $(3-)^{[6]}$ and octaborate(2- $)^{[7]}$ anions. We have also recently reported some novel species containing copper $(2+)^{[8,9]}$ centers and this manuscript reports a new $\mathrm{Cu}(\mathrm{II})$ salt partnered by two pentaborate(1-) anions. The structure of a pentaborate(1-) anion, containing one tetrahedral and four trigonalplanar boron centres, is drawn schematically in Figure 1(a).

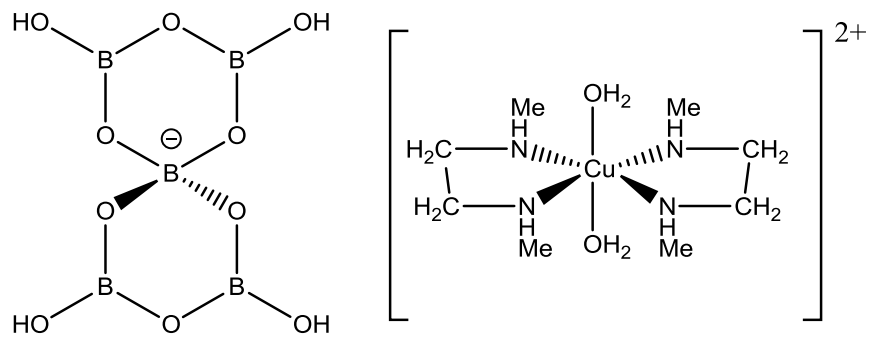

(a)

Figure 1. Schematic structures of (a) the pentaborate(1-) anion, $\left[\mathrm{B}_{5} \mathrm{O}_{6}(\mathrm{OH})_{4}\right]^{-}$, and (b) the octahedral $\mathrm{Cu}$ (II) cation, $\left[\mathrm{Cu}(\mathrm{dmen})_{2}\left(\mathrm{H}_{2} \mathrm{O}\right)_{2}\right]^{2+}$ found in 1.

\section{RESULTS AND DISCUSSION}

The new $\mathrm{Cu}(\mathrm{II})$ polyborate $\left[\mathrm{Cu}(\text { dmen })_{2}\left(\mathrm{H}_{2} \mathrm{O}\right)_{2}\right]\left[\mathrm{B}_{5} \mathrm{O}_{6}(\mathrm{OH})_{4}\right]_{2} \cdot 2 \mathrm{~B}(\mathrm{OH})_{3}$ (1) $($ dmen $=N, N$ '-dimethylethylenediamine, $\mathrm{MeHNCH}_{2} \mathrm{CH}_{2} \mathrm{NHMe}$ ) has been prepared according to Scheme 1 through a crystallization processes in basic aqueous solution involving a templating $\mathrm{Cu}$ (II) amine complex and $\mathrm{B}(\mathrm{OH})_{3}$. The precursor $\mathrm{Cu}(\mathrm{II})$ complex, $\left[\mathrm{Cu}(\mathrm{dmen})_{2}\right] \mathrm{Cl}_{2} \cdot \mathrm{H}_{2} \mathrm{O}$, was prepared by modifying a literature procedure in excellent yield. ${ }^{[10]}$ 


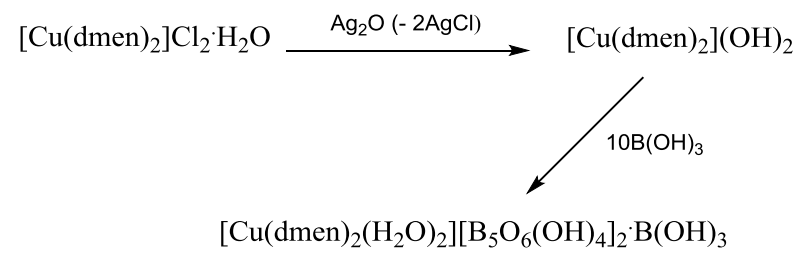

(1)

Scheme 1. Synthesis of the copper(II) pentaborate, $\left[\mathrm{Cu}(\text { dmen })_{2}\left(\mathrm{H}_{2} \mathrm{O}\right)_{2}\right]\left[\mathrm{B}_{5} \mathrm{O}_{6}(\mathrm{OH})_{4}\right]_{2} \cdot 2 \mathrm{~B}(\mathrm{OH})_{3}(\mathbf{1})(\mathrm{dmen}$ $=N, N$ '-dimethylethylenediamine, $\mathrm{MeHNCH}_{2} \mathrm{CH}_{2} \mathrm{NHMe}$ ).

The product $\mathbf{1}$ crystallized out from aqueous solution in moderate (48\%) yield after several days at room temperature. The product arises through alkaline hydrolysis/condensation of the $\mathrm{B}(\mathrm{OH})_{3}$ and its subsequent crystallization from the solution. The reaction solution is a rich source of a variety of anions and cations ${ }^{[11,12]}$ since polyborate anions are in facile equilibrium in basic aqueous solution ${ }^{[13,14]}$ and $\mathrm{Cu}(\mathrm{II})$ amine complexes are also known ${ }^{[15]}$ to be labile. Stoichiometery, $\mathrm{pH}$, and energetics associated with crystal packing, steric congestion, hydrogen bonding, and coordination bond formation all have a role to play in many, and probably this, crystallization processes. ${ }^{[16,17]}$

Compound 1 has been characterized by thermal studies (TGA/DSC), magnetic susceptibility measurements, elemental analyses, IR spectroscopy and single-crystal XRD studies.

The thermal TGA/DSC data obtained for 1 (see supplementary material) were consistent with the structure determined by single-crystal X-ray diffractions studies (see below) and were also consistent with thermal decomposition in air to the anhydrous copper borate with stoichiometry $\mathrm{CuB}_{12} \mathrm{O}_{19}$ (= $\mathrm{CuO} \cdot 6 \mathrm{~B}_{2} \mathrm{O}_{3}$ ). This product is formed via a stepwise process involving loss of coordinated $\mathrm{H}_{2} \mathrm{O}$, borate condensation, and finally ligand oxidation; such behavior has been previously observed for other metal complex polyborate salts. ${ }^{[6-9,18-20]}$

Elemental analyses data were consistent with the single-crystal structures indicating that the bulk sample was homogeneous and that the crystal chosen for XRD studies was representative.

Compound 1 displays strong bands in the B-O stretching region (1450-750 $\left.\mathrm{cm}^{-1}\right)$ which have been assigned to either symmetric or asymmetric B-O stretches to three or four-coordinate boron centres. ${ }^{[21]}$ In particular, a strong band at $921 \mathrm{~cm}^{-1}$ (sym $\left.\mathrm{B}_{\text {trig- }} \mathrm{O}\right)$ is observed and this is reported to be diagnostic of the pentaborate(1-) anion. ${ }^{[22]}$ 
The ${ }^{11} \mathrm{~B}$ NMR spectrum of $\mathbf{1}$ is also typical of that for a pentaborate(1-) $\operatorname{salt}^{[1,4,5]}$ with signals associated with $\mathrm{B}(\mathrm{OH})_{3} /\left[\mathrm{B}(\mathrm{OH})_{4}\right]^{-} \quad(17.5 \quad \mathrm{ppm}) \quad$ and $\left[\mathrm{B}_{3} \mathrm{O}_{3}(\mathrm{OH})_{4}\right]^{-}(13.5 \mathrm{ppm})$ visible due to rapid borate exchange processess. ${ }^{[13,14]}$

${ }^{1} \mathrm{H}$ and ${ }^{13} \mathrm{C}$ spectra were not obtainable for $\mathbf{1}$. This may be due to the proximity of the dmen ligand to the paramagnetic $\left(d^{9}\right) \quad \mathrm{Cu}(\mathrm{II})$ centre. The magnetic susceptibility of $\mathbf{1}$ was in accord with other paramagnetic mono-copper(II) polyborate salts. ${ }^{[8]}$

Compound $\mathbf{1}$ is formulated as an ionic compound comprised of a copper(II) complex cation, $\quad\left[\mathrm{Cu}\left(\mathrm{MeNHCH}_{2} \mathrm{CH}_{2} \mathrm{~N}-\right.\right.$ $\left.\mathrm{MeH})_{2}\left(\mathrm{H}_{2} \mathrm{O}\right)_{2}\right]^{2+}$, with insular $\left[\mathrm{B}_{5} \mathrm{O}_{6}(\mathrm{OH})_{4}\right]^{-}$ anions. The crystal structure for $\mathbf{1}$ showing the asymmetric unit and indicating atomic numbering scheme is given in Figure 2. The cation is drawn schematically in Figure 1(b). The cation in $\mathbf{1}$ is centrosymmetric with the central $\mathrm{Cu}(\mathrm{II})$ in an elongated tetragonal octahedral geometry $\left(T^{6}=0.85\right)^{[23]}$ with the coordinated $\mathrm{H}_{2} \mathrm{O}$ molecules axial and trans with Cu1-O21 at 2.4263(14) A. The equatorial $\mathrm{Cu} 1-\mathrm{N} 21$, and $\mathrm{Cu} 1-\mathrm{N} 22$ distances are 2.0621(16) $\AA$ and 2.0430(16) $\AA$, respectively. These data are unremarkable and similar to those observed in related copper(II) amine complexes. ${ }^{[8,23]}$

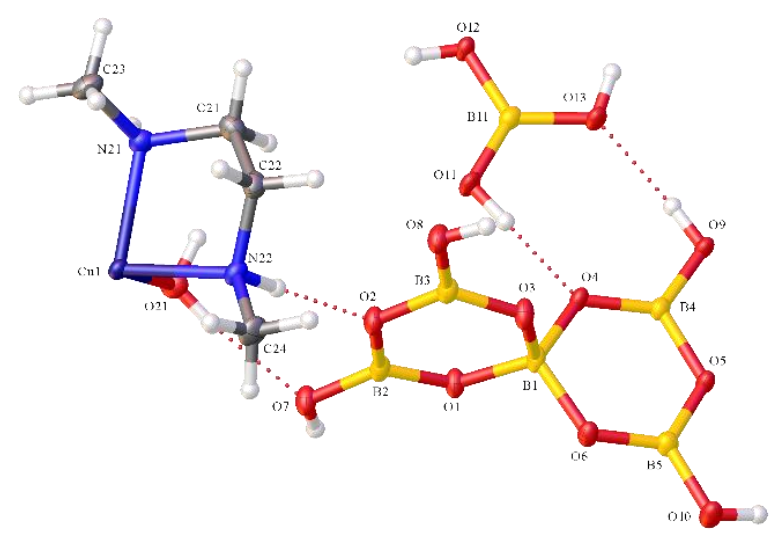

Figure 2. Asymmetric unit of $\mathbf{1}$ showing two different $\mathrm{R}_{2}^{2}(8)$ H-bond intercations

Bond angles and distances for the $\left[\mathrm{B}_{5} \mathrm{O}_{6}(\mathrm{OH})_{4}\right]^{-}$anions are unexceptional and are in accord with other known pentaborate structures. $^{[1-5]}$ There is a $\mathrm{B}(\mathrm{OH})_{3}$ of crystallization for each pentaborate(1-) anion and these two structural units are hydrogen bonded together via $\mathrm{R}_{2}^{2}(8)$ (Etter nomenclature ${ }^{[24]}$ ) motifs (Figure 2). In addition, H-bond donor sites on the coordinated $\mathrm{MeNHCH}_{2} \mathrm{CH}_{2} \mathrm{NMeH}$ and $\mathrm{H}_{2} \mathrm{O}$ ligands further stabilize the structure through interactions with acceptor sites on a pentaborate(1-) anion in a $\mathrm{R}_{2}^{2}(8)$ motif $(\mathrm{NH}$, $\mathrm{OH}$ donors; shown in Figure 2). The pentaborate(1-) anions and boric acid 
molecules link together to form a giant $\mathrm{H}$ bond supramolecular network with the $\mathrm{B}(\mathrm{OH})_{3}$ units acting as 'spacers' to help accommodate the large templating cation within the lattice (Figure 3). ${ }^{[25]}$ Details of all these H-bond interactions are in the supplementary information.

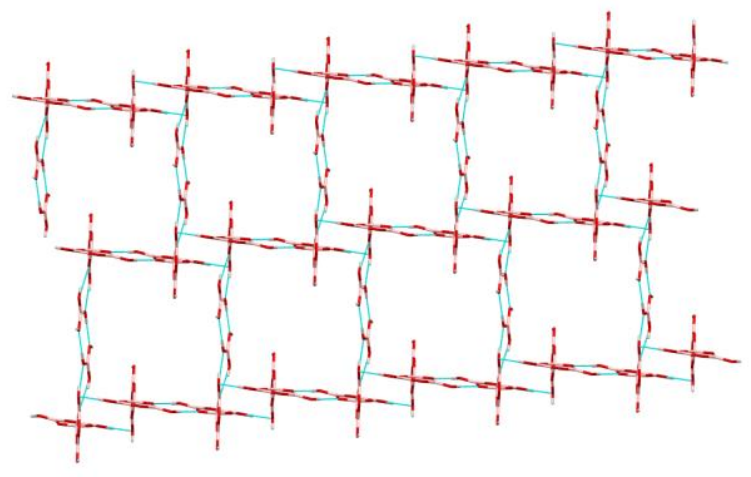

Figure 3. A view of a plane of pentaborate(1-) anions and spacer $\mathrm{B}(\mathrm{OH})_{3}$ molecules. The copper(II) complex cations (not shown) are in the centres of the squares.

\section{EXPERIMENTAL}

General. All chemicals were obtained commercially. FTIR spectra were obtained (KBr pellets) on a Perkin-Elmer 100 FTIR spectrometer. NMR spectra were obtained on a Bruker Avance 400 spectrometer and reported in ppm with positive chemical shifts
( $\delta)$ to high frequency (downfield) of TMS $\left({ }^{1} \mathrm{H},{ }^{13} \mathrm{C}\right)$ and $\mathrm{BF}_{3} \cdot \mathrm{OEt}_{2}\left({ }^{11} \mathrm{~B}\right)$. TGA/DSC analysis (in air) were performed on an SDT Q600 V4.1 Build 59 instrument using $\mathrm{Al}_{2} \mathrm{O}_{3}$ crucibles, between $10-800{ }^{\circ} \mathrm{C}$ with a ramp temperature rate of $10{ }^{\circ} \mathrm{C} \mathrm{min}^{-1}$. Singlecrystal X-ray crystallography was carried out at the EPSRC National Crystallography service at the University of Southampton. CHN analysis was obtained from OEA laboratories Ltd in Callington, Cornwall.

\section{Synthesis of $\left[\mathrm{Cu}(\mathrm{dmen})_{2}\right] \mathrm{Cl}_{2} \cdot \mathrm{H}_{2} \mathrm{O}$ :}

$\mathrm{CuCl}_{2} \cdot 2 \mathrm{H}_{2} \mathrm{O}$ (4.1 g, $\left.24 \mathrm{mmol}\right)$ was dissolved in ethanol $(40 \mathrm{~mL})$ to give a clear green solution. $N, N$ '-dimethylethylenediamine (5.2 $\mathrm{mL}, 47 \mathrm{mmol})$ in ethanol $(10 \mathrm{~mL})$ was added dropwise to the green solution which was left to stir for 10 minutes. The resulting dark blue solution was placed in an ice bath for 2 hours until a dark blue precipitate formed. The precipitate was collected by filtration and washed with $\mathrm{Et}_{2} \mathrm{O}(2 \times 5 \mathrm{~mL})$ and dried for $30 \mathrm{~min}$ in desiccator. Yield: $7.5 \mathrm{~g}$ (95\%). M.p.: $209-211{ }^{0} \mathrm{C} . \chi_{\mathrm{m}}: 9.5 \times 10^{-4} \mathrm{~cm}^{3} \mathrm{~mol}^{-1}$. $\mathrm{C}_{8} \mathrm{H}_{26} \mathrm{CuN}_{4} \mathrm{OCl}_{2}$. Anal. Calc.: $\mathrm{C}=29.2 \%, \mathrm{H}$ $=8.0 \%, \mathrm{~N}=17.0 \%$; Found: $\mathrm{C}=29.5 \%, \mathrm{H}$ $=8.0 \%, \mathrm{~N}=17.0 \%$ FT-IR $(\mathrm{KBr})$ $\left(v_{\max } / \mathrm{cm}^{-1}\right): 3495(\mathrm{~s}), 3220(\mathrm{~s}), 2921$ (m), 
1453 (s), 1421 (m), 1089 (m), 1065 (m), 1022 (s), 983 (m), 973 (s), 862 (m), 467 (m).

Synthesis, spectroscopic and analytical data for 1: $\left[\mathrm{Cu}(\mathrm{dmen})_{2}\right] \mathrm{Cl}_{2} \cdot \mathrm{H}_{2} \mathrm{O}(1.00 \mathrm{~g}, 3$ $\mathrm{mmol}$ ), and $\mathrm{Ag}_{2} \mathrm{O}$ (0.746 g, $\left.3 \mathrm{mmol}\right)$ were rapidly stirred in $\mathrm{H}_{2} \mathrm{O}(25 \mathrm{~mL})$ at room temperature for 30 minutes. The $\mathrm{AgCl}$ precipitate which formed was removed by filtration. $\mathrm{B}(\mathrm{OH})_{3}(1.99 \mathrm{~g}, 32 \mathrm{mmol})$ was added to the dark blue filtrate which was left to stir for a further 30 minutes. The reaction mixture was again filtered and the filtrate placed in small vials and left for slow evaporation of the solvent to occur. After 7 days, blue crystals (1.2 g, $48 \%)$ of $\mathbf{1}$, $\left[\mathrm{Cu}\left(\mathrm{MeNHCH}_{2} \mathrm{CH}_{2} \mathrm{NHMe}\right)_{2}\left(\mathrm{H}_{2} \mathrm{O}\right)_{2}\right]$

$\left[\mathrm{B}_{5} \mathrm{O}_{6}(\mathrm{OH})_{4}\right]_{2} \cdot 2 \mathrm{~B}(\mathrm{OH})_{3}$, had formed. These were collected by filtration and dried in desiccator M.p. $=>300{ }^{0} \mathrm{C} . \chi_{\mathrm{m}}=8.0 \times 10^{-4}$ $\mathrm{cm}^{3} \mathrm{~mol}^{-1}$. $\mathrm{C}_{8} \mathrm{H}_{42} \mathrm{~B}_{12} \mathrm{CuN}_{4} \mathrm{O}_{28}$. Anal. Calc.: $\mathrm{C}$ $=11.5 \%, \mathrm{H}=5.1 \%, \mathrm{~N}=6.7 \%$. Found: $\mathrm{C}=$ $11.3 \%, \mathrm{H}=5.3 \%, \mathrm{~N}=6.6 . \mathrm{NMR}:{ }^{11} \mathrm{~B} / \mathrm{ppm}$ $17.5(90 \%), 13.5(10 \%) . \quad I R\left(\mathrm{KBr} / \mathrm{cm}^{-1}\right)$ : 3463(m), 3261(s), 1451(s), 1325(s), 1156(m), 1083(m), 1042(m), 1019(m), 921(s), 773(m), 706(m). TGA: $30-100{ }^{\circ} \mathrm{C}$, loss of two coordinated $\mathrm{H}_{2} \mathrm{O}$, and three $\mathrm{H}_{2} \mathrm{O}$ from $\mathrm{B}(\mathrm{OH})_{3}$ condensation $10.1 \%(10.7 \%$ calc.); $\quad 150-240 \quad{ }^{0} \mathrm{C}$, condensation of polyborate which loss of four $\mathrm{H}_{2} \mathrm{O} 18.2 \%$ (19.3\% calc.); $280-450{ }^{\circ} \mathrm{C}$, oxidation of organic content $41.6 \%$ (40.5\% calc.); residual $\mathrm{CuB}_{12} \mathrm{O}_{19} 58.4 \%$ (59.5\% calc.).

X-ray crystallography. A suitable crystal of 1 was selected and mounted on a MITIGEN holder in perfluoroether oil on a Rigaku FRE+ equipped with HF Varimax confocal mirrors an $\mathrm{AFC12}$ goniometer and $\mathrm{HG}$ Saturn 724+ detector diffractometer. Crystals was kept at $\mathrm{T}=100(2) \mathrm{K}$ during data collection. Using Olex2, ${ }^{[26]}$ the structure was solved with the ShelXT ${ }^{[27]}$ structure solution program, using the Intrinsic Phasing solution method. The model were refined with version 2014/7 of ShelXL ${ }^{[28]}$ using Least Squares minimisation.

Crystallographic data. 1: $\mathrm{C}_{8} \mathrm{H}_{42} \mathrm{~B}_{12} \mathrm{CuN}_{4} \mathrm{O}_{28}$, $M_{r}=835.71$, triclinic, P-1 (No. 2), $\mathrm{a}=$ 8.5093(3) $\mathrm{A}, \quad \mathrm{b}=$ 9.4281(3) $\mathrm{A}, \quad \mathrm{c}=$ 10.5503(3) $\AA, \quad \alpha=100.340(3)^{\circ}, \quad \beta=$ $90.409(2)^{\circ}, \quad \gamma=101.096(3)^{\circ}, \quad V=$ 816.34(5) $\AA^{3}, T=100(2) \mathrm{K}, Z=1, Z^{\prime}=0.5$, $\mu\left(\operatorname{MoK}_{\alpha}\right)=0.780 \mathrm{~mm}^{-1}, 18141$ reflections measured, 3732 unique $\left(R_{\text {int }}=0.0380\right)$ which were used in all calculations. The final $w R_{2}$ was 0.0989 (all data) and $R_{l}$ was 0.0362 (I > $2 \sigma(\mathrm{I}))$. 


\section{CONCLUSIONS}

A new $\mathrm{Cu}(\mathrm{II}) /$ borate complex (1) has been crystallized from aqueous solution with a $\mathrm{Cu}: \mathrm{B}$ ratio of 1:6. Compound $\mathbf{1}$ is a pentaborate(1-) salt with one interstitial $\mathrm{B}(\mathrm{OH})_{3}$ per pentaborate(1-) unit. The role of the $\mathrm{B}(\mathrm{OH})_{3}$ is to expand the $\mathrm{H}$-bonded pentaborate(1-) lattice to accommodate the large octahedral $\quad\left[\mathrm{Cu}(\mathrm{dmen})_{2}\left(\mathrm{H}_{2} \mathrm{O}\right)_{2}\right]^{2+}$ cations.

\section{Acknowledgements.}

We thank the EPSRC for the NCS X-ray crystallographic service (Southampton).

\section{Supplemental Materials.}

${ }^{11} \mathrm{~B}$ and IR spectra and a plot of the DSC analysis are available as supplementary information. Crystallographic data for the structural analysis of compound $\mathbf{1}$ is available as supplementary information and has also been deposited at the Cambridge Crystallographic Data Center (CCDC number 1881683). Copies of the information may be obtained free of charge from The Director, CCDC, 12 Union Road, Cambridge CB2 1 EZ, UK (Fax: +44-1223-336033; email: $\quad$ deposit@ccdc.cam.ac.uk or www.ccdc.cam.ac.uk).

\section{REFERENCES}

[1] Beckett, M. A. Recent advances in crystalline hydrated borates with non-metal or transitionmetal cations. Coord. Chem Rev. 2016, 323, 214. DOI: 10.1016./j.ccr.2015.12.012

[2] Wiebcke, M.; Freyhardt, C.C.; Felsche, J.; Engelhardt, G. Clathrates with three-dimensional host structures of hydrogen bonded pentaborate $\left[\mathrm{B}_{5} \mathrm{O}_{6}(\mathrm{OH})_{4}\right]^{-}$ions: pentaborates with the cations $\mathrm{NMe}_{4}{ }^{+}, \mathrm{NEt}_{4}{ }^{+}, \mathrm{NPhMe}_{3}{ }^{+}$and $\mathrm{pipH}^{+}\left(\mathrm{pipH}^{+}=\right.$ piperidinium). Z. Naturforsch. 1993, 48b, 978985.

[3] Visi, M.Z.; Knobler, C.B.; Owen, J.J.; Khan, M.I.; Schubert, D.M. Structures of selfassembled nonmetal borates derived from $\alpha, \omega-$ diaminoalkanes. Cryst. Growth Des. 2006, 6, 538-545. DOI: 10.1021/cg0504915

[4] Beckett, M A.; Bland, C. C.; Horton, P. N.; Hursthouse, M. B.; Varma, K. S. Supramolecular structures containing 'isolated' pentaborate anions and non-metal cations: crystal structures of $\left[\mathrm{Me}_{3} \mathrm{NCH}_{2} \mathrm{CH}_{2} \mathrm{OH}\right]\left[\mathrm{B}_{5} \mathrm{O}_{6}(\mathrm{OH})_{4}\right]$ and [4MepyH,4-Mepy][ $\left.\mathrm{B}_{5} \mathrm{O}_{6}(\mathrm{OH})_{4}\right]$. J. Organomet. Chem. 2007, 692, 2831-2838. DOI: 10.1016/j.jorganchem.2007.02.038.

[5] Beckett, M. A.; Coles, S. J.; Davies, R. A.; Horton, P. N.; Jones, C. L. Pentaborate(1-) salts template by substituted pyrrolidinium cations: synthesis structural characterization, and modelling of solid-state $\mathrm{H}$-bond interactions by DFT calculations. Dalton Trans. 2015, 44, 7032 7040, DOI: 10.1039/c5dt00248f

[6] Altahan, M. A.; Beckett, M. A.; Coles, S. J.; Horton, P. N. A new polyborate anion 
$\left[\mathrm{B}_{7} \mathrm{O}_{9}(\mathrm{OH})_{6}\right]^{3-}$ : self-assembly, XRD and thermal properties of $s-f a c-\left[\mathrm{Co}(\text { dien })_{2}\right]\left[\mathrm{B}_{7} \mathrm{O}_{9}(\mathrm{OH})_{6}\right] \cdot 9 \mathrm{H}_{2} \mathrm{O}$ Inorg. Chem. Commun. 2015, 59, 95-98. DOI: 10.1016/j.inoche.2015.07.011

[7] Altahan, M. A.; Beckett, M. A.; Coles, S. J.; Horton, P. N. A new decaoxidooctaborate(2-) anion, $\left[\mathrm{B}_{8} \mathrm{O}_{10}(\mathrm{OH})_{6}\right]^{2-}$ : Synthesis and characterization of $\left[\mathrm{Co}(\mathrm{en})_{3}\right]\left[\mathrm{B}_{5} \mathrm{O}_{6}(\mathrm{OH})_{4}\right]$ $\left[\mathrm{B}_{8} \mathrm{O}_{10}(\mathrm{OH})_{6}\right] \cdot 5 \mathrm{H}_{2} \mathrm{O}(\mathrm{en}=1,2$-diaminoethane $)$. Inorg. Chem. 2015, 54, 412-414. DOI: 10.1021/ic5027834

[8] Altahan, M. A.; Beckett, M. A.; Coles, S. J.; Horton, P. N. Synthesis and characterization of polyborates templated by cationic copper(II) complexes: structural (XRD), spectroscopic, thermal (TGA/DSC) and magnetic properties. Polyhedron 2017, 135, 247-257.

DOI:10.1016/poly.2017.07.016

[9] Altahan, M. A.; Beckett, M. A.; Coles, S. J.; Horton, P. N. Synthesis and characterization by a single-crystal XRD study of

$\left[\mathrm{H}_{3} \mathrm{O}\right]_{4}\left[\mathrm{Cu}_{7}\left(\mathrm{NH}_{3}\right)_{2}\left(\mathrm{H}_{2} \mathrm{O}\right)_{4}\left\{\mathrm{~B}_{24} \mathrm{O}_{39}(\mathrm{OH})_{12}\right\}\right] 13 \mathrm{H}_{2} \mathrm{O}$ : an unusual bis(hydroxytrioxidoborate) trimetallic chain supported by a [ $\left\{\mathrm{Cu}_{4} \mathrm{O}\right\}\left\{\mathrm{B}_{20} \mathrm{O}_{32}(\mathrm{OH})_{8}\right]^{6-}$ cluster. J. Cluster Sci. 2018, 219, 1337-1343. DOI: 10.1007/s10876018-1452-9

[10] Cui, A.-L.; Chen, X.; Sun, L; Wei, J.-Z.; Yang, Y.; Kou, H.-Z. Preparation and thermochromic properties of copper(II)- $N, N$ diethylethylenediamine complexes. J. Chem.

Educ. 2011, 88, 311-312. DOI:

10.1021/ed100103a

[11] Corbett, P. T.; Leclaire, J.; Vial, L; West, K. R.; Wietor, J.-L.; Sanders, J. K. M.; Otto, O.
Dynamic combinatorial chemistry. Chem. Rev., 2006, 106, 3652-3711 DOI: 10.1021/cr020452p

[12] Sola, J.; Lafuente, M; Atcher, J; Alfonso, I. Constitutional self-selection from dynamic combinatorial libraries in aqueous solution through supramolecular interactions. Chem. Commun. 2014, 50, 4564-4566. DOI: $10.1039 / \mathrm{c} 4 \mathrm{cc} 00245 \mathrm{~h}$.

[13] Salentine, C. G. High-field ${ }^{11}$ B NMR of alkali borates. Aqueous polyborate equilibria. Inorg. Chem. 1983, 22, 3920-3924. DOI:

10.1021/ic00168a019.

[14] Anderson, J.L.; Eyring, E.M.; Whittaker, M.P. Temperature jump rate studies of polyborate formation in aqueous boric acid. J. Phys. Chem.

1964, 68, 1128-1132. DOI: $10.1021 / \mathrm{j} 100787 \mathrm{a} 027$

[15] Taube, H. Rates and mechanisms of substitutions of inorganic complexes in aqueous solution.

Chem. Rev. 1952, 50, 69-126. DOI:

$10.1021 / \mathrm{cr} 60155 \mathrm{a} 003$

[16] Dunitz, J.D.; Gavezzotti, A. Supramolecular synthons: validation and ranking of intermolecular interaction energies. Cryst. Growth Des. 2012, 12, 5873-5877. DOI: $10.1021 / \mathrm{cg} 301293 \mathrm{r}$.

[17] Desiraju, G.R. Supramolecular synthons in crystal engineering - a new organic synthesis. Angew Chem. Int. Ed. Engl. 1995, 34, 23112327. DOI: 10.1002/anie.199523111

[18]Zheng, L.; Zhang, J. Liu, Z. Synthesis, crystal structure and thermal behaviour of $\mathrm{Coen}_{3}\left[\mathrm{~B}_{4} \mathrm{O}_{5}(\mathrm{OH})_{4}\right] \mathrm{Cl} \cdot 3 \mathrm{H}_{2} \mathrm{O}$ and $\mathrm{Nien}_{3}\left[\mathrm{~B}_{5} \mathrm{O}_{6}(\mathrm{OH})_{4}\right]_{2} \cdot 2 \mathrm{H}_{2} \mathrm{O}$ Chin. J. Chem. 2009, 27, 494-500. 10.1002/cjoc.200990081 
[19]Liu, Z.-H., Zhang, J.-J., Zhang, W.-J. Synthesis, crystal structure and vibrational spectroscopy of a novel mixed ligands $\mathrm{Ni}(\mathrm{II})$ pentaborate:

$\left[\mathrm{Ni}\left(\mathrm{C}_{4} \mathrm{H}_{10} \mathrm{~N}_{2}\right)\left(\mathrm{C}_{2} \mathrm{H}_{8} \mathrm{~N}_{2}\right)_{2}\right]\left[\mathrm{B}_{5} \mathrm{O}_{6}(\mathrm{OH})_{4}\right]_{2}$ Inorg.

Chim. Acta 2006, 359, 519-524. DOI:

10.1016/j.ica.2005.10.008

[20] Yang, Y.; Wang, Y.; Zhu, J. Liu, R.-B., Xu, J, Meng, C.-G. A new mixed-ligand copper pentaborate with square-like, rectangle-like and ellipse-like channels formed via hydrogen bonds. Inorg. Chem. Acta 2011, 376, 401-407. DOi: 10.1016/j.ica.2011.06.051

[21]Li, J.; Xia, S.; Gao, S. FT-IR and Raman spectroscopic study of hydrated borates. Spectrochim. Acta, 1995, 51A, 519-532. DOI: 0584-8539(94)00183-9

[22] Beckett, M.A.; Horton, P.N.; Coles, S.J.; Kose, D.A.; Kreuziger, A.-M. Polyhedron, 2012, 38, 157- 161. DOI: 10.1016/j.poly.2012.02.031

[23] Hathaway, B. J.; Hodgson, P. G. Copper-ligand bond-lengths in axial complexes of copper(II) ion. J. Inorg. Nucl. Chem. 1973, 35, 4071-4081. DOI:

[24] Etter, M. C. Encoding and decoding hydrogenbond patterns of organic chemistry. Acc. Chem. Res. 1990, 23, 120-126. DOI: 10.1021/ar00172a005

[25] Beckett, M.A.; Coles, S. J.; Horton, P. N.; Jones, C. L. Polyborate anions partnered with large nonmetal cations: triborate(1-) pentaborate(1-) and heptaborate(2-) salts. Eur. J. Inorg. Chem. 2017, 4510-4518. DOI: 10.1002/ejic.201700551

[26] Dolomanov, O. V.; Bourhis, L. J.; Gildea, R. J.; Howard, J. A. K.; Puschmann, H. Olex2: a complete structure solution, refinement and analysis program. J. Appl. Cryst. 2009, 42, 339341. DOI: 10.1107/S0021889808042726

[27] Sheldrick, G. M. ShelXT-intergrated spacegroup and crystal structure determination, Acta Cryst. 2015, A71, 3-8. DOI:

$10.1107 / \mathrm{S} 2053273314026370$

[28] Sheldrick, G. M. Crystal structure refinement with ShelXL, Acta Cryst. 2015, C27, 3-8. DOI: $10.1107 /$ S2053229614024218 